\title{
Space and time variations in zooplankton distribution south of Marseilles
}

\author{
Raymond GAUDY, Gisèle CHAMPALBERT \\ Centre d'océanologie de Marseille, CNRS UMR 6535, station marine d'Endoume, rue de la Batterie-des-Lions, \\ 13207 Marseille, France
}

(Revised 19 June 1998, accepted 3 September 1998)

\begin{abstract}
The mesozooplankton distribution in the upper water layer (up to $200 \mathrm{~m}$ ) off Marseilles (NW Mediterranean Sea) was studied during 22 cruises performed between March 1992 and February 1995. Four stations (M1, M3, M5 and M7) were investigated along a coast-open sea transect. Spatial and seasonal variations of zooplankton were described using different quantitative parameters: biomass (dry weight, carbon, nitrogen), displacement volume (biovolume) and abundance of total organisms. $\mathrm{C} / \mathrm{N}$ ratio, dry weight per individual and volume per individual were also calculated. The seasonal quantitative variations occurring at the four stations were not well synchronized. Annual maximum biomass was observed during spring and summer at Ml but only in early spring at the other stations. Abundance and biovolumes followed the same general pattern of variation. The mean values of the different parameters were maximum near the coast, at M1, and minimum at the most distant station (M7), but the decrease towards the open sea was not regular: the values found at M5 were higher than at M3 and markedly exceeded those at M7. This seems to be related to the presence of the oligotrophic Northern Mediterranean Current flowing parallel to the coast. In most cases M3 was in the core of the current whereas M5 seemed to be frequently influenced by its external boundary. Locally, this frontal situation enhanced the primary production and consequently favoured an increase in zooplankton biomass or production as suggested by the strong temporal correlation between chlorophyll and zooplankton at this station. Comparison between stations demonstrated the specificity of M5 zooplankton which showed the lowest variability in its specific dry weight and biovolume and the highest $\mathrm{C} / \mathrm{N}$ ratios. (C) Elsevier, Paris
\end{abstract}

zooplankton / space-time distrihution / open-coast sea gradient / northwestern Mediterranean

Résumé - Variations spatiales et temporelles de la répartition du zooplancton au sud de Marseille. La distribution du mésozooplancton dans la couche d'eau superficielle (jusqu'à $200 \mathrm{~m}$ ) au large de Marseille (Méditerranée nord-occidentale) a été étudiée lors de 22 sorties entre mars 1992 et février 1995. Quatre stations (M1, M3, M5 et M7) ont été prospectées le long d'une radiale côte-large. Les variations spatiales et saisonnières du zooplancton sont décrites à partir de différents paramètres quantitatifs : la biomasse (poids sec, carbone, azote), le volume déplacé (biovolume) et l'abondance de l'ensemble des organismes. Les rapports carbone/azote, poids sec par individu et volume par individu ont aussi été calculés. Les variations quantitatives saisonnières observées aux quatre stations sont mal synchronisées. Le maximum annuel de bionasse observé au printemps et en été à M I était limité au début du printemps aux autres stations. L'abondance et le biovolume suivaient le même type de variation. Les biovolumes atteignaient parfois de très hautes valeurs à M1 et M3, correspondant à la présence d'animaux gélatineux. Lés valeurs moyennes des différents paramètres étaient maximales près de la côte à Ml et minimales à la station la plus éloignée (M7), mais leur décroissance vers le large n'était pas régulière. En cffet, les valeurs rencontrées à M5 étaient plus fortes qu'à M3 et surpassaient nettement celles de M7. Cette anomalie positive du gradient est en relation avec la présence des eaux oligotrophes du courant méditerranéen nord occidental parallèle à la côtc. Dans la plupart des cas, M3 était au cour du courant alors que M5 semblait fréquemment influencée par sa limite externe. Localement, cette situation frontale stimule la production primaire et favorise l'accroissement de la biomasse ou de la production zooplanctonique, comme le suggère la forte corrélation entre la chlorophylle et le zouplancton à cette station. Des comparaisons entre les stations montrent le caractère original présenté par le zooplancton de M5 : la variabilité de ses valeurs spécifiques de poids sec et de biovolume est la plus faible et il présente les rapports $\mathrm{C} / \mathrm{N}$ les plus élevés. (c) Elsevier, Paris

zooplancton / distribution spatio-temporelle / gradient côte-large / Méditerannée nord-occidentale 


\section{INTRODUCTION}

Seasonal variations of the quantity of zooplankton have been studied for many decades. The range of variation strongly depends on latitude: maximal in cold regions and much narrower in tropical regions. The seasonality is directly related to phytoplankton cycles characterised by an intense but short period of algal growth at high latitudes while, in tropical regions, seasonal variations of chlorophyll biomass are dampened through the year [14]. In temperate regions, zooplankton generally displays several seasonal peaks, the main one in spring, the others during autumn or summer. In the Mediterranean Sea, numerous studies show that this temperate pattern is the general rule $[11,13,20,21]$.

Most zooplankton cycles have been studied in coastal waters, which are more accessible and thus allow more regular sampling. There are fewer data from offshore waters and many of them are limited to seasonal observations [19], or only concern particular taxa such as copepoda $[7,8,9]$. As it is impossible to ascertain whether the seasonal variations of oceanic zooplankton are synchronous or not with coastal ones, this lack of data is a handicap in estimating the time variations of the grazing pressure exerted by zooplankton when a large marine region is considered. It is generally believed that zooplankton abundance decreases along an inshorc-offshorc. We may wonder whether this rule applies in areas characterised by strong hydrographic discontinuities such as geostrophic currents flowing parallel to the coast.

Within the Mediterranean research subproject of the Programme national d'océanographie côtière (PNOC), we sampled mesozooplankton collected along a coast-offshore transect, south of Marseilles, repeatedly over a period of three years. This allowed us to complete the scarce data existing on zooplankton biomass and abundance of this region, and also to compare the seasonal cycles of coastal and offshore zooplankton and to examine the influence of the North Mediterranean Current on the decreasing gradient of zooplankton abundance towards the open sea.

\section{MATERIALS AND METHODS}

Zooplankton was collected during successive cruises (SUIVILION and PROCEPEL programs) by vertical hauls (200 $\mathrm{m}$ to the surface), using a WPII standard $200 \mu \mathrm{m}$ net [26]. Most zooplankton biomass is located in this water layer [20] and most quantitative investigations on Mediterranean zooplankton have adopted this method of sampling [2]. Biovolume was measured by displacement [26]: zooplankton sample was first screened through a gauze disk. This disk was put on a shect of absorbent paper for $15 \mathrm{~min}$ to remove the interstitial water, then rolled to form a cylinder allowing it to be introduced into a $10 \mathrm{~mL}$ measuring cylinder. The biovolume was calculated as the difference between the observed volume and the known displacement volume of the gauze disk. Dry weight was obtained after oven drying of total zooplankton at $67{ }^{\circ} \mathrm{C}$ for $24 \mathrm{~h} \mathrm{[16].} \mathrm{Carbon}$ and nitrogen contents were measured using a LECO 830 $\mathrm{CHN}$ analyser. Zooplankton organisms were counted with subsample fractions of the total collection adjusted to allow the counting of at least 200 individuals.

Detailed data on temperature, salinity and chlorophyll (from December 1992 to June 1994) come from Conan's study [5]. They were obtained at the same stations and for corresponding sampling periods, but not always the same day (within 0 to 6 days) because it was difficult to complete the hydrological and planktonical programs simultaneously. Complementary data on the upper $80 \mathrm{~m}$ were obtained from a CTD M.E. equipped with a fluorometer.

Sampling stations M1, M3, M5 and M7 were located along a north-south transect off Marseilles at $5^{\circ} 12.5 \mathrm{E}$ longitude, and $43^{\circ} 10,43^{\circ} 02,42^{\circ} 56$ and $42^{\circ} 50$ latitude. M1 and M3 were over $90 \mathrm{~m}$ and $1000 \mathrm{~m}$ depth, M5 and M7 over $1500 \mathrm{~m}$ (figure I).

\section{RESULTS}

The temperature, salinity and chlorophyll $a$ profiles are presented in figure 2. The seasonal variation of chlorophyll integrated values between the surface and $100 \mathrm{~m}$ are shown in figure 3. For zooplankton quantitative variations, a variance analysis performed on all the data showed that average dry weight, carbon, nitrogen, $\mathrm{C} / \mathrm{N}$, volume and abundance were all significantly different among sampling dates and stations (table $I$ ).

\subsection{Seasonal variations}

At the intermediate stations M3 and M5 (figure 4) the zooplankton biomass (expressed in dry weight, carbon or nitrogen units) was at its maximum in March or April. At the offshore station $\mathrm{M} 7$, the maximum appeared earlier in 1994 (no dala for spring 1992 and 1993). Conversely, at 


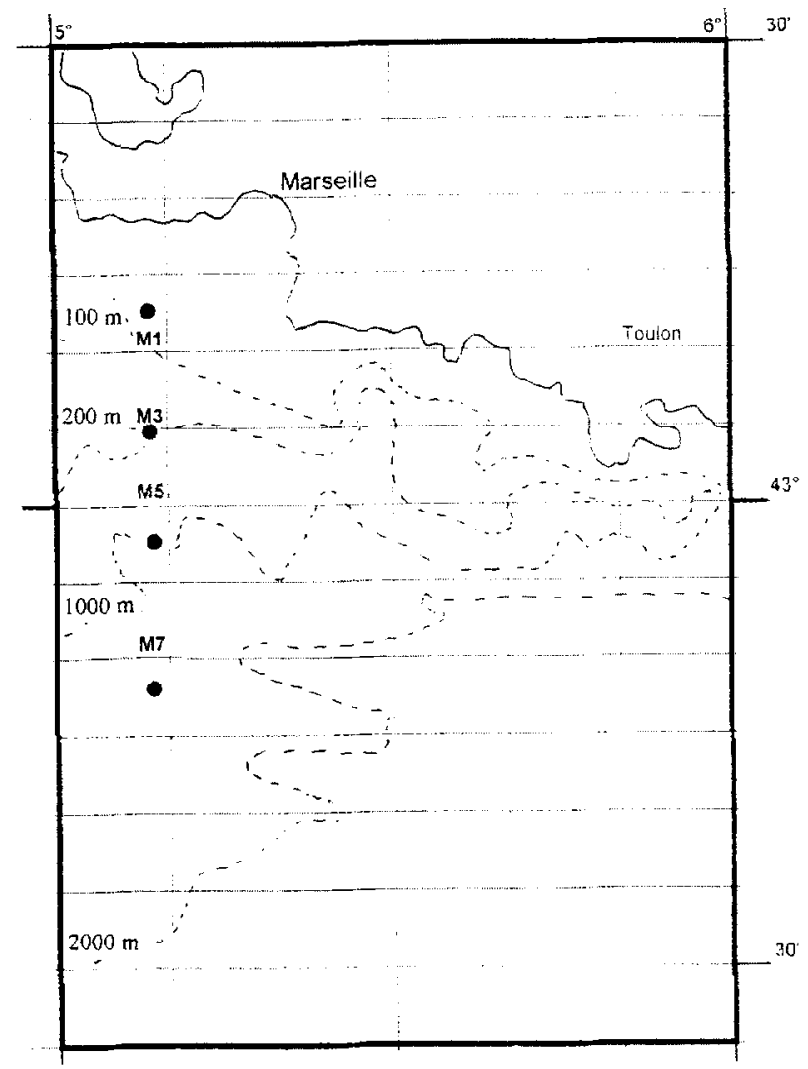

Figure 1. Study site and position of stations along the PNOC transect.

the station closest to the coast (MI), late spring or summer hiomass are relatively high (June 1992, June 1993. May and August 1994). A period of high biomass was also observed during winter 1994. The lack of synchrony in the biomass cycle of zooplankton at the different stations is statistically confirmed by a Kolmogorov-Smirnov test carried out to compare the seasonal distribution at M3, M5 and M7 with the distribution observed at M1 considered as reference. Zooplankton biovolumes vary as biomass, but very large values corresponding to blooms of gelatinous animals (salps, medusa) were recorded at $\mathrm{M} 1$ and $\mathrm{M} 2$ on some occasions. Individual numbers also vary as biomass and biovolumes; however they were poorly correlated with biomass in comparison with the correlations existing between dry weight, carbon and nitrogen (table II). Abundance and biovolumes were also poorly correlated with each other.

The relationships between zooplankton biomass and chlorophyll abundance between December 1992 and June 1994 are shown in table IV. Correlations were significant at M3 and highly significant at M5, but not significant at the two other stations.

\subsection{Spatial variations}

When the whole data set was considered, the average biomass differed according to the stations, regardless of the unit used (dry weight, carbon or nitrogen) (table II). The highest was found at M1, closest to the coast, and the lowest at M7, the most oceanic station. Nevertheless, the decrease in biomass towards the open sea was not uniform. Decline was rapid between M1 and M3 (statistically significant: $t=1.73$ ). At M5 the biomass of zooplankton was higher than at $\mathrm{M} 3$ and $\mathrm{M} 7$ but significantly different only from $M 7: t=2.14$ ). It was close to the value obtained near the coast despite a distance of more than $30 \mathrm{~km}$. Biovolumes also were higher at M1 than at M3 $(t=2.09)$ and at M5 than at M3 (not significant at $\mathrm{P}=0.05)$ or $\mathrm{M} 7(\mathrm{t}=3.58)$. The abundance showed the same pattern; decrease between MI and M3 was significant $(\mathrm{t}=2.04)$ and the minimum value was obtained at M7. A break in the gradient was also observed at M5 (the difference being significant only for M7). $\mathrm{C} N \mathrm{~N}$ ratios were slightly higher at $\mathrm{M} 5$ and $\mathrm{M} 7$ than at $\mathrm{M} 1$ and $\mathrm{M} 3$.

The average dry weight per individual was highest at the offshore station but this difference was not significant because of the large variability occurring during the year at M7. The average biovolume per individual was also strongly variable and similar at the four stations.

\section{DISCUSSION}

Seasonal variations in dry weight, carbon and nitrogen were strongly correlated. Conversely, displacement volumes and abundance were rather poorly correlated to biomass variations. This could be due either to the variability caused by complex handling necessary to measure biovolume or by the diversity of individual body size throughout the year (see below)

The high values of standard deviation of the mean values per station of zooplankton descriptors can be explained by the range of their seasonal variations. These variations are often related to phytoplanktonic cycles. This is the case only for M3 and M5, as indicated by the correlation existing between chlorophyll abundance and zooplankton biomass, particularly at M5 where $r$ reached a very high value. 

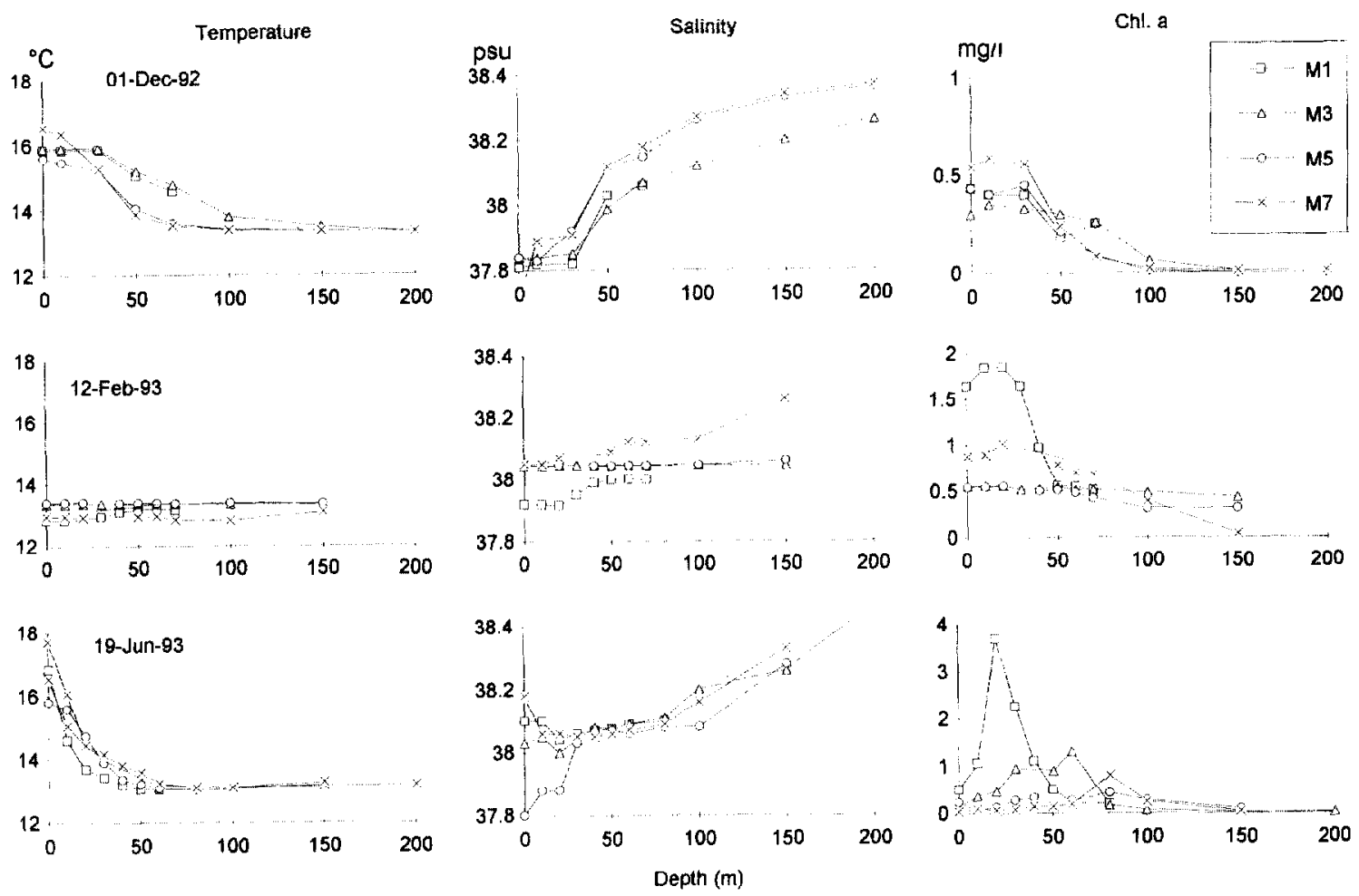

Temperature

Salinity

Ch. a
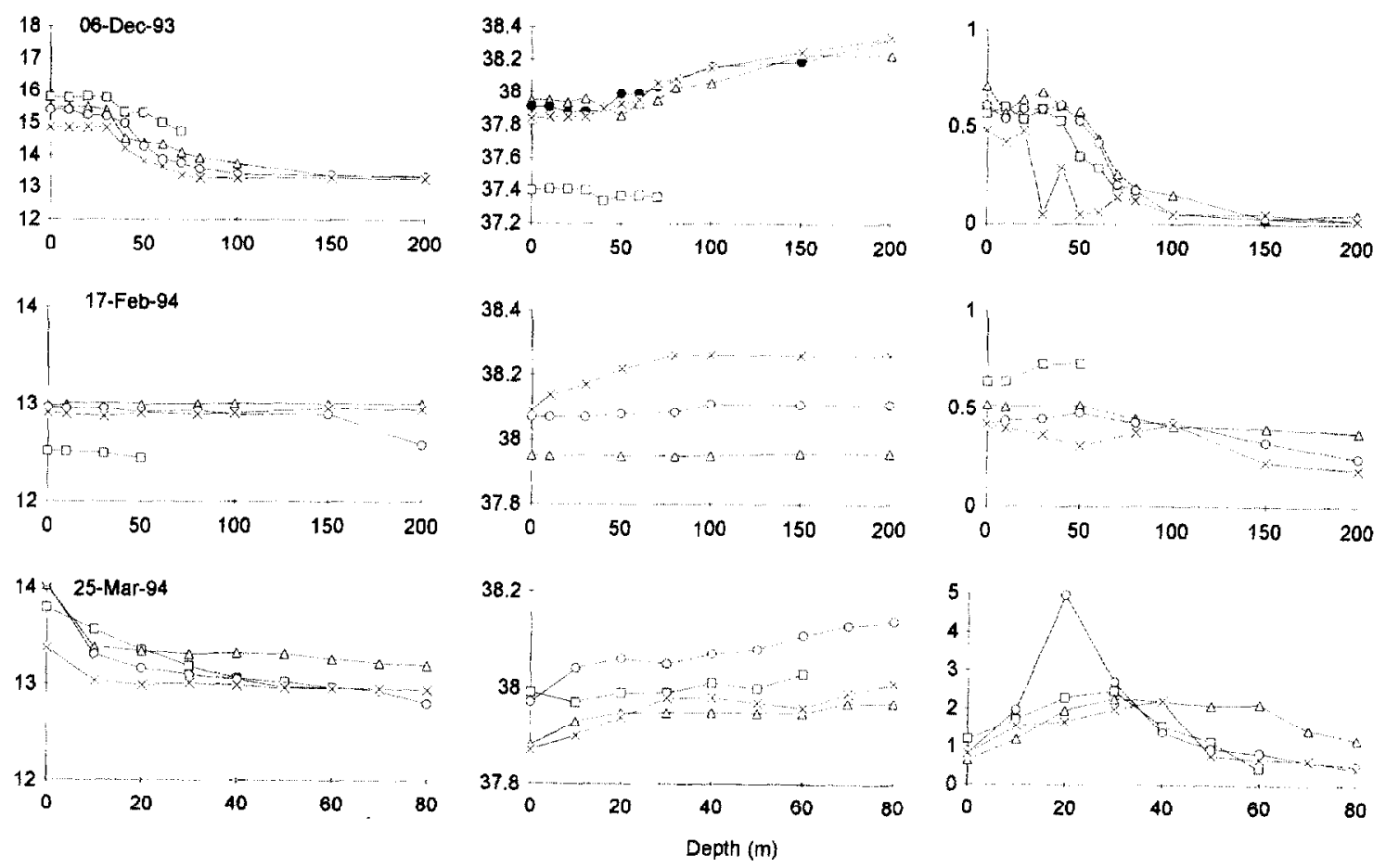
Temperature


Salinity
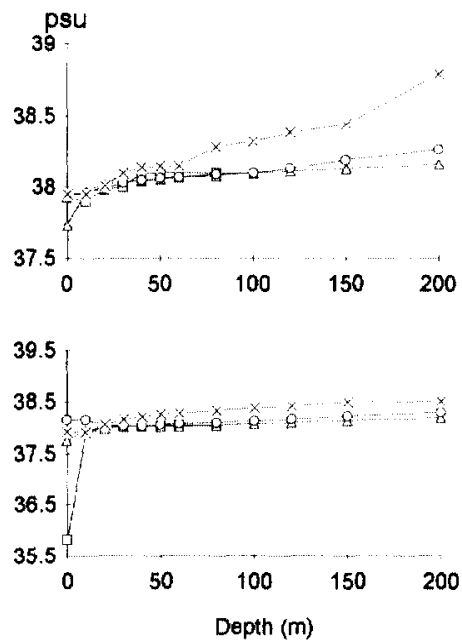

Chl. a
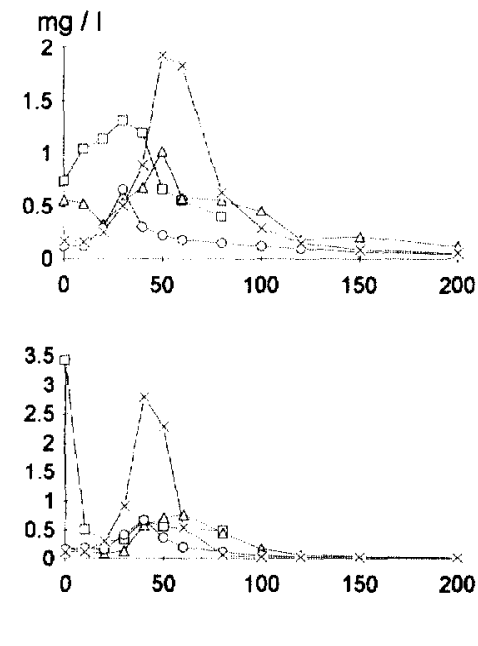
$\leftarrow \uparrow$

Figure 2. Temperature, salinity and chlorophyll $a$ profiles at the four station during the period December 1992-June 1994.

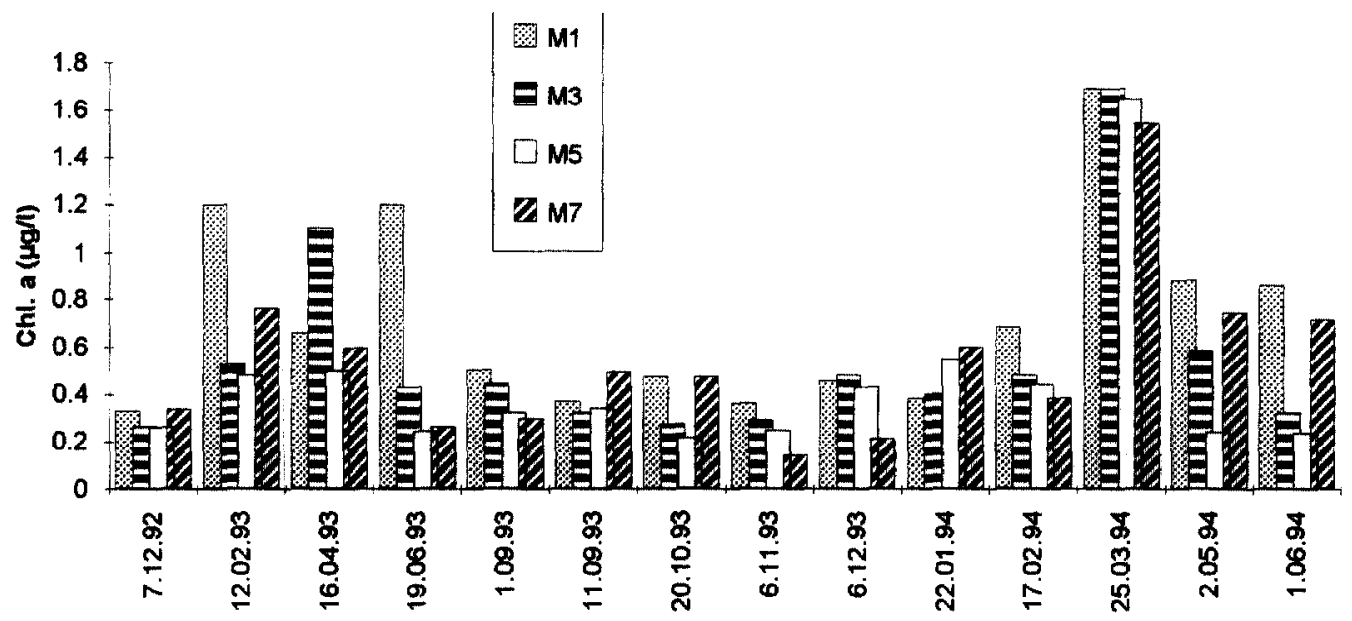

Figure 3. Seasonal variations of chlorophyll $a$ concentration (integrated values between 0 and $100 \mathrm{~m}$ ) at the four stations during the period Decemher 1992-June 1994

The seasonal distribution pattern of total zooplankton at the most coastal station with a spring-summer period of maximal abundance is typical of northwestern Mediterranean cycles, as shown by several authors, among them Gilat et al. [13] at Monaco, Gaudy [11] at Marseilles, Razouls [20] at Banyuls or Seguin [21] at Villefranche. The abundance cycle observed at the other stations was relatively poorly synchronized with the coastal cycle. The earlier main biomass peak (February-March), observed in this study at offshore stations (M5, M7), was previously observed at another Mediterranean oceanic station near Calvi, in Corsica [6]. Interannual variations of zooplankton abundance also seem to occur, but we do not have enough repeated seasonal data to dicuss this point.

The average values of all descriptive quantitative parameters used in this study show that the decreasing coastopen sea gradient usually observed for zooplankton dis- 
Table I. ANOVA performed on total data: values of $F$ and significance levels $(P)$. $d f=21$ for date and 3 for stations.

\begin{tabular}{lcccc}
\hline Parameter & \multicolumn{2}{c}{ Date } & \multicolumn{2}{c}{ Stations } \\
\cline { 2 - 5 } & F & P & F & P \\
\hline Dry weight & 1.80 & $<0.0378$ & 3.09 & $<0.0331$ \\
Carbon & 1.96 & $<0.0205$ & 2.83 & $<0.0455$ \\
Nitrogen & 1.88 & $<0.0281$ & 3.63 & $<0.0175$ \\
C/N & 3.01 & $<0.0004$ & 2.18 & $<0.0993$ \\
Biovolume & 2.65 & $<0.0016$ & 6.69 & $<0.0001$ \\
Abundance & 1.90 & $<0.0264$ & 2.85 & $<0.0444$ \\
\hline
\end{tabular}

tribution [17] is modified by the presence of contrasting high values at more than $30 \mathrm{~km}$ from the coast which seems related to the Northwestern Mediterranean Current flowing parallel to the coast. According to Conan's studies [5], in the same area and at the same time, this current is characterised by its narrowness, its location nearer the coast and its higher speed in winter, and by a more offshore location, a wider extension and a lower speed in summer. From Conan's data, station M3 is the site most often influenced by the core of the NWMC, particularly during winter when the current approaches the coast. Nevertheless M3 is also periodically influenced by coastal water. Christaki et al. [4] demonstrated that, at the M3 station, the pelagic food web (from bacteria to zooplankton) alternated from oligotrophy, dominated by heterotrophs, when the station was in the NWMC, to eutrophy when it was influenced by the inner edge of the core current or by coastal water. In both conditions, the zooplankton assemblage was similar, but its nutritional physiology was modified as indicated by experimentally observed changes in its ammonia excretion rate, depending on the nature of food (prevailing plant or animal material). Such hydrodynamic features induced increased variability of zooplankton parameters at the intermediate stations compared to M1 (table II). Fairly often M5 was located at the external limit of the current [5]. Vertical advection processes linked to the secondary circulation are frequently associated with current fronts [15]. Such processes may lead to high chlorophyll densities at the two limits of the current [5]. At M5, average zooplankton biomass was maximum but chlorophyll concentrations were generally similar or lower than at M3 and M7. Nevertheless, the highest correlation coefficient between zooplankton biomass and chlorophyll values recorded throughout the annual cycle was found at M5, suggesting that food quality was more suitable for zooplanktondevelopment at this station. Rich chlorophyll conditions favour zooplankton density by increasing its secondary production. This was demonstrated in several types of fronts $[12,17,22,23,24]$. In the Ligurian sea, in the eastern part of the NWMC, several zooplankton species were maximally abundant at the frontal system, as shown by Boucher et al. [1] who demonstrated that the distribution of the herbivorous copepod Calanus helgolandicus was directly related to the presence of the front where it seemed to reproduce actively and that some other 7.00plankton species concentrated in this zone during their reproduction period. Gasser [10] also indicated that juvenile stages of siphonophores were abundant at the front limit in June.

Table II. Annual means of some zooplankton descriptive parameter $(\mathrm{m} \pm \mathrm{sd}$; number of data: $\mathrm{MI}=18 ; \mathrm{M} 3=22 ; \mathrm{M} 5=15 ; \mathrm{M} 7=17)$.

\begin{tabular}{|c|c|c|c|c|}
\hline Parameter & M1 & M3 & M5 & M7 \\
\hline $\begin{array}{l}\text { Dry wejght } \\
\left(\mathrm{mg} \mathrm{m}^{3}\right)\end{array}$ & $3.56 \pm 2.42$ & $2.26 \pm 2.13$ & $3.00 \pm 2.75$ & $1.43 \pm 0.78$ \\
\hline $\begin{array}{l}\text { Carbon } \\
\left(\mathrm{mg} \mathrm{m}^{-3}\right)\end{array}$ & $0.83 \pm 0.51$ & $0.68 \pm 0.72$ & $0.85 \pm 0.91$ & $0.32 \pm 0.26$ \\
\hline $\begin{array}{l}\text { Nigrogen } \\
\left(\mathrm{mg} \mathrm{m}^{-3}\right)\end{array}$ & $0.22 \pm 0.17$ & $0.16 \pm 0.16$ & $0.17 \pm 0.16$ & $0.07 \pm 0.06$ \\
\hline $\mathrm{C} / \mathrm{N}$ & $4.31 \pm 0.16$ & $4.46 \pm 0.19$ & $4.90 \pm 0.28$ & $4.70 \pm 0.15$ \\
\hline $\begin{array}{l}\text { Biovolume } \\
\left(\mathrm{mm}^{3} \mathrm{~m}^{-1}\right)\end{array}$ & $24.4 \pm 22$ & $11.9 \pm 13.8$ & $13.6 \pm 7.4$ & $5.9 \pm 4.1$ \\
\hline $\begin{array}{l}\text { Abundance } \\
\text { (ind. } \mathrm{m}^{-3} \text { ) }\end{array}$ & $682 \pm 493$ & $392 \pm 425$ & $508 \pm 698$ & $244 \pm 179$ \\
\hline Carbon/volume & $0.046 \pm 0.02$ & $0.077 \pm 0.062$ & $0.066 \pm 0.041$ & $0.056 \pm 0.034$ \\
\hline $\begin{array}{l}\text { Dry weight/ind. } \\
(\mu \mathrm{g})\end{array}$ & $7.71 \pm 6.57$ & $8.59 \pm 7.44$ & $10.47 \pm 7.73$ & $26.86 \pm 49.52$ \\
\hline $\begin{array}{l}\text { Volume/ind. } \\
\left(10^{-3} \mathrm{~mm}^{3}\right)\end{array}$ & $0.05 \pm 50.064$ & $0.040 \pm 0.043$ & $0.058 \pm 0.043$ & $0.068 \pm 0.097$ \\
\hline
\end{tabular}



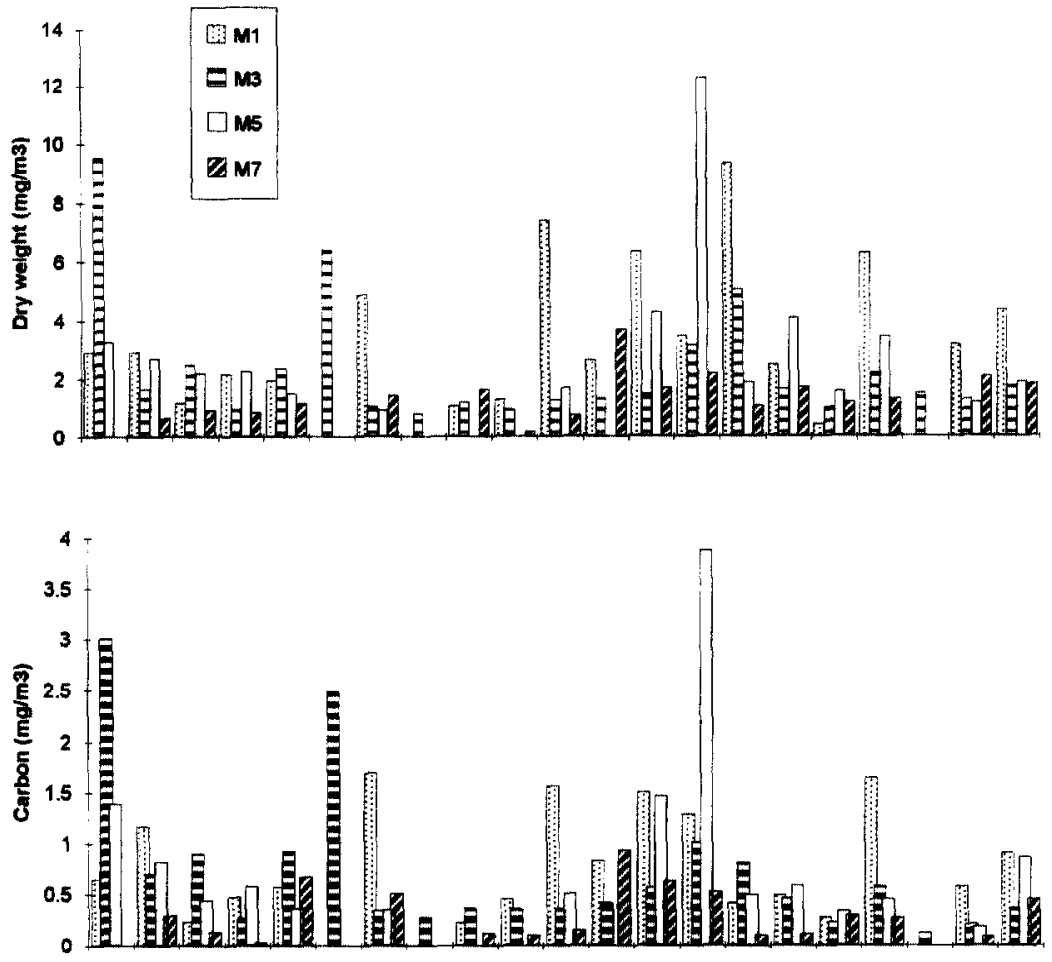

(a)
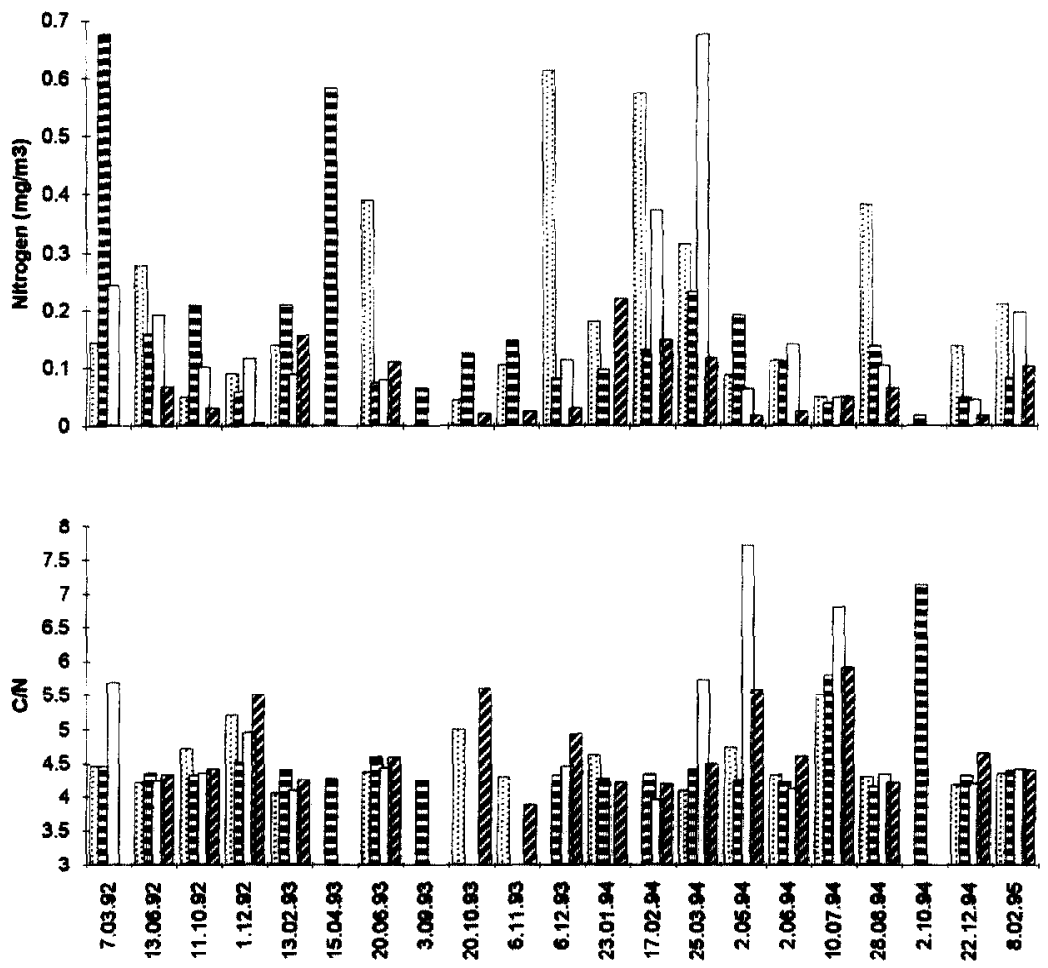

Figure 4. See next page. 


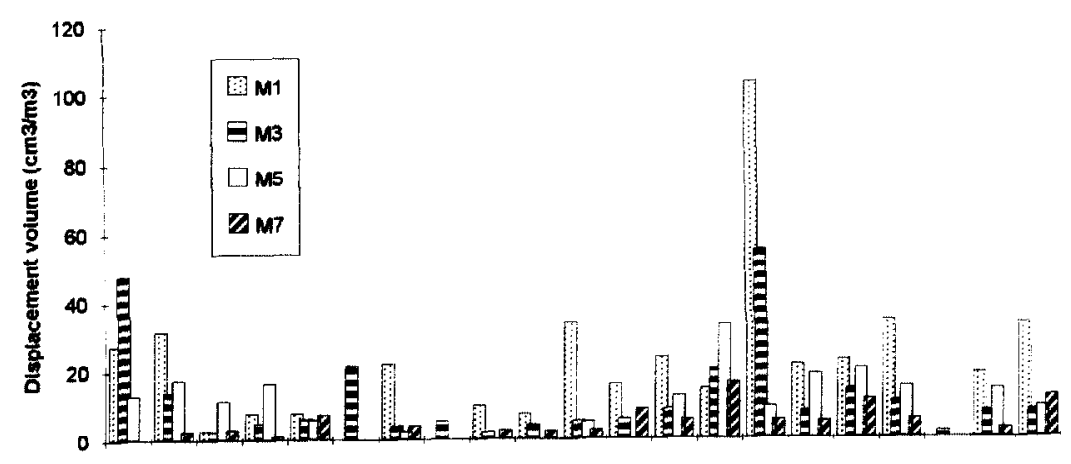

(b)

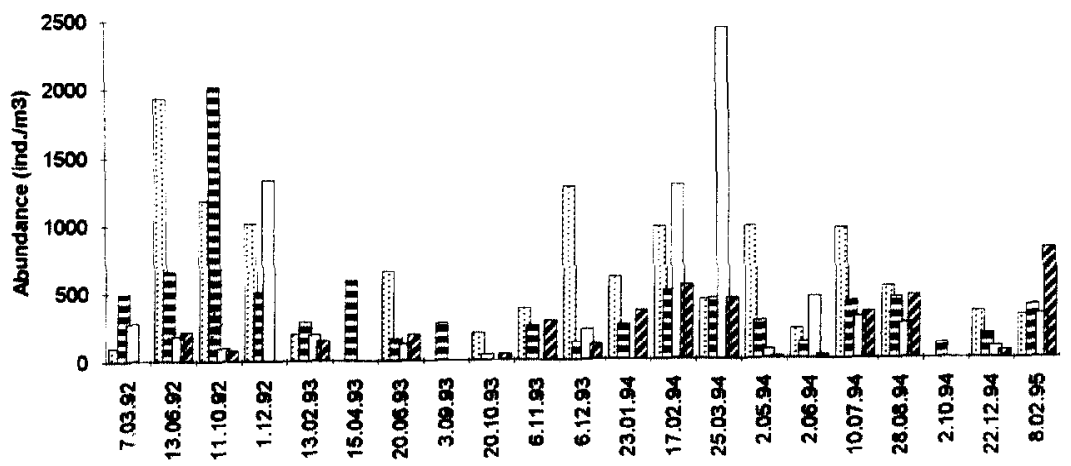

Figure 4. Seasonal variations of zooplankton dry weight, Carbon, $\mathrm{C} / \mathrm{N}$ ratio (a), displacement volume and abundance (b) at the four stations.

Table III. Correlation between volume, dry weight and abundance of zooplankton at the different stations: values of $r$. ns $=$ non-significant at $P<0.05$.

\begin{tabular}{lllll}
\hline Factors & M1 & M3 & M5 & M7 \\
\hline Biovolume/abundance & $0.398 \mathrm{~ns}$ & $0.025 \mathrm{~ns}$ & 0.821 & 0.628 \\
Dry weight/abundance & $0.329 \mathrm{~ns}$ & $0.174 \mathrm{~ns}$ & 0.863 & $0.450 \mathrm{~ns}$ \\
Dry weight/biovolume & 0.749 & 0.929 & 0.894 & 0.622 \\
\hline
\end{tabular}

Table IV. Correlation between zooplankton dry weight and Chlorophyll $a$ at the different stations. $\mathrm{ns}=$ non-significant; * significant at $P<0.05 ; * *$ significant at $P<0.01$.

\begin{tabular}{lcccc}
\hline & M1 & M3 & M5 & M7 \\
\hline Correlation coefficient $(r)$ & 0.21 & 0.48 & 0.91 & 0.20 \\
Number of data & 12 & 15 & 9 & 12 \\
Significant value & ns & $*$ & $* *$ & ns \\
\hline
\end{tabular}

Among the relationships existing between the different descriptive parameters, the correlations of abundance are the poorest (table $I$ ). This may result from the variability caused by the succession of different species or development stages during the year. For example, during life cycles, similar biomass can be reached when individuals are young (small sized and numerous) and when they are older (large and scarce). So there is no reason to expect strong correlations between abundance and biomass or volume. 

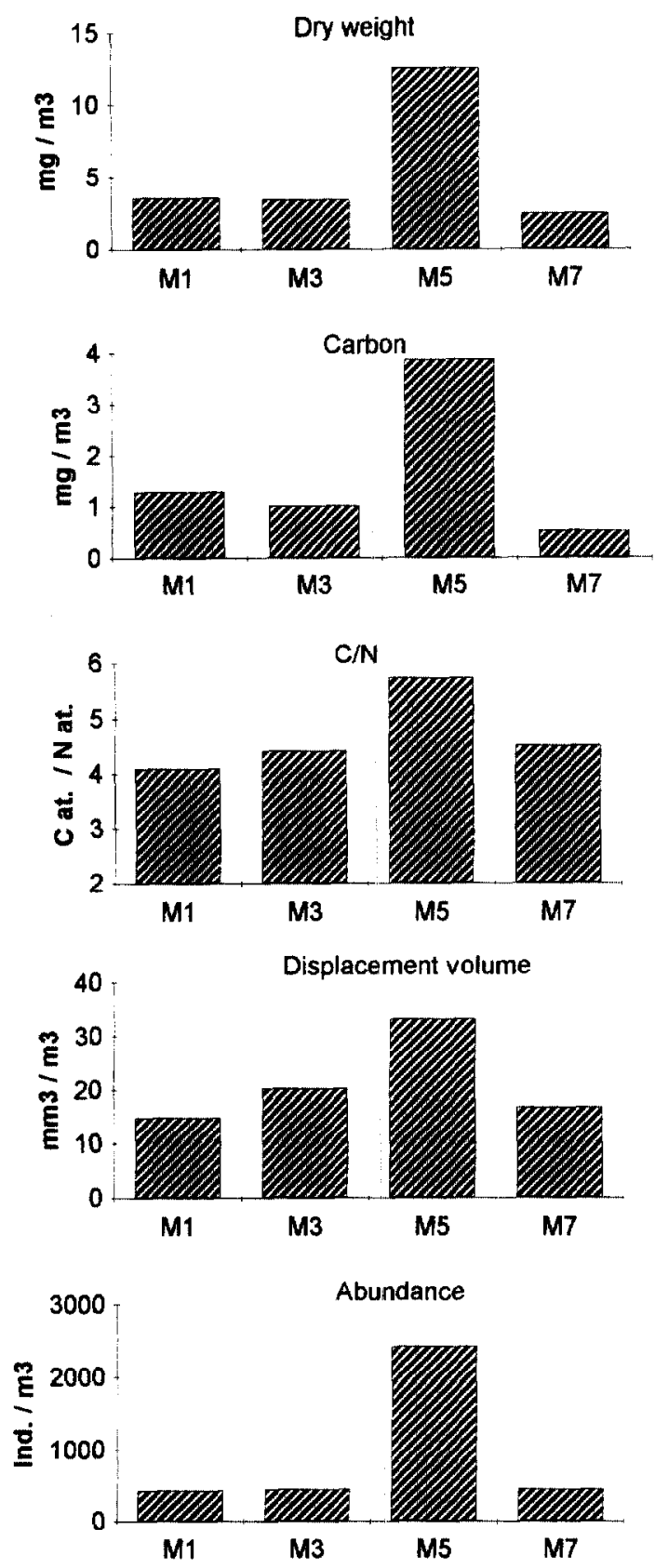

Figure 5. March 251994 cruise. Zooplankton dry weight, Carbon, $\mathrm{C} / \mathrm{N}$ ratio, displacement volume and abundance at the four stations.

When the different stations are considered separately (table III), biovolumes and biomass remain well correlated at each station. In contrast, correlations between abundance and either biomass or biovolume are high only at M5 and low or absent at the other stations. These results suggest that zooplankton composition is more homogeneous at M5 than at the other stations during the year. This is also suggested by the smaller variability of dry weight per individual and volume per individual at M5 than at M3 or M7 (table II). Moreover, the highest $\mathrm{C} / \mathrm{N}$ ratios were found at M5. All these observations and the high biomass at M5 indicate the original character of zooplankton at this station. The strong correlation between zooplankton biomass and chlorophyll at M5 contrasts with the lower correlation found at M3 and near zero correlation at the other stations. A strong relationship between primary and secondary biomass seems characteristic of frontal regions [24], in which the aggregation or the production of a limited number of well adapted phytophageous species is favoured [1, 17]. Such features could explain the lower variability of specific dry weights and volumes observed at M5. According to some preliminary observations, the zooplankton assemblage was less diverse at M5 than at other stations, and was mainly dominated by copepods belonging to genus Clausocala$n u s$ ( $C$. pergens; $C$. furcatus). During the period December 1992-June 1994, we observed that zooplankton abundances were clearly higher at M5 than at M3 and/or M7 at several occasions (1/12/92; 17/02/94;25/ $0.3 / 94 ; 2 / 06 / 94)$. Refering to salinity and chlorophyll profiles (figure 2), it appears that M5 was located at the external front limit, taking into account its higher salinity $(1 / 12 / 92,17 / 02 / 94 ; 25 / 03 / 94)$ or chlorophyll values $(1 / 12 / 92 ; 25 / 03 / 94 ; 2 / 06 / 94$, between 0 and $40 \mathrm{~m})$ compared to M3 conditions. During the March 25, 1994 cruise (figure 5), the biomass was considerably higher at M5 than at the other stations. The $\mathrm{C} / \mathrm{N}$ ratio of 5.7 of zooplankton then clearly exceeded the values, of about 4.5 , at neighbouring stations. The zooplankton was very abundant and dominated $(95 \%$ of the total number) by the copepod Clausocalanus pergens. The corresponding hydrographic data at this station showed saltier and colder water than elsewhere, as well as a strong chlorophyll peak located closer to the surface than in adjacent waters (figure 2). These findings suggest that a limited upwelling related to the secondary circulation associated to the front limit could have induced a strong, local algal production successfully exploited by a particular zooplankton species. Although such conditions were never found so markedly during other cruises, such mechanisms could be frequent at M5, thus explaining the particular distribution of the zooplankton quantitative parameters along the coastopen sea transect, clearly apparent on an annual basis. 


\section{REFERENCES}

[1] Boucher J., Déterminisme et dynamique de la répartition spatiale des populations de copépodes des zones de résurgences côtières nord-est Atlantiques et du front Liguro-Provençal, Univ. Paris-VI, Thèse Doct. Sci. (1987) 185 p.

[2] Boucher J., Thiriot A., Zooplancton et micronecton des deux cents premiers mètres en Méditerranée Occidentale, Mar. Biol. 15 (1972) 47-56.

[3] Boucher J., Ibanez F., Prieur L., Daily and seasonal variations in the spatial distribution of zooplankton populations in relation to the physical structure in the Ligurian Sea Front, J. Mar. Res. 45 (1987) 133-173.

[4] Christaki U., Van Wambeke F., Christou E., Conan P., Gaudy R., Food web structure variability in the surface layer, at a fixed station influenced by the North Western Mediterranean Current, Hydrobiol. 321 (1996) 145-153.

[5] Conan P., Variabilité et bilan de la production primaire en zone côtière (Méditerranée Nord Occidentale; entrée du Golfe du Lion) en relation avec les systemes biologiques, chimiques et hydrodynamiques (Courant Nord Méditerranéen). Univ. Méditerranée, Thèse Doct. (1996) $185 \mathrm{p}+$ annexes.

[6] Dauby P., Cycle annuel du zooplancton de surface de la baie de Calvi (Corse), Biomasse totale et plancton copépodien, Oceanol. Acta 3 (1980) 403-407.

[7] Fleminger A., Distributional atlas of calanoid copepods in the California Current region, Part I, in: Calcofi Atlas $\mathrm{N}^{\circ} 2$, Fleminger A., Klein H.Y., (Eds.), Mar. Res. Comittee, State Calif., $1964,313 \mathrm{p}$.

[8] Fleminger A., Distributional atlas of calanoid copepods in the California Current region, Part 2, in: Calcofi Atlas $N^{\circ} 7$. Fleminger A., Klein H.Y., (Eds.), Marine Res. Comittee, State of California, 1967, $213 \mathrm{p}$.

[9] Grice G.D., Hart A.D., The abundance, seasonal occurrence and distribution of the epizooplankton between New York and Bermuda, Ecol. Monogr. 32 (1962) 287-309.

[10] Gasser B., La structuration verticale des communautés mésozooplanctoniques à travers des fronts hydrodynamiques, Univ. Paris VI. Thèse Doct. (1996) $162 \mathrm{p}+$ annexes.

[11] Gaudy R., Contribution à l'étude du cycle biologique des copépodes pélagiques du Golfe de Marseille I. L'environnement physique et biotique et la composition de la population de copépodes, Tethys 3 (4) (1972) 92I-942.

[12] Gaudy R., Bianchi M., Pagano M., Soto Y., Cross frontal variability in hydrological and biological structures observed in a river plume area (Rhône mouth; NW Mediterranean Sea), Hydrobiologia 324 (1996) 131-140.
[13] Gilat E., Kane J.E., Martin J.C., Study of an Ecosystem in the Coastal waters of the Ligurian Sea. II Surface zooplankton, Bull. Inst. Océanogr. Monaco, 65, 1353 (1965) 1-56.

[14] Heinrich A.K., Les cycles des animaux planctoniques et les variations saisonnières des communautés planctoniques dans les océans, J. Cons. perm. int. Explor. Mer 27 (1963) 15-23.

[15] Le Pichon X., Troadec J.P., La couche superficielle de la Méditerranée au large des côtes provençales durant les mois d'été, Cah. Océanogr. 5 (1966) 299-319.

[16] Lovegrove $T$., The determination of the dry weight of plankton and the effect of various factors on the values obtained, in: Some contemporary studies in marine science, Barnes $H$., (Ed.), London. Allen and Unwin LTd, 1966, 429-467.

[17] Mackas D.L., Louttit G.C., Aggregation of the copepod Neocalanus plumchrus at the margin of the Fraser River plume in the Strait of Georgia, Bull. mar. Sci. 43 (1988) 810-824.

[18] Mackas D.L., Washburn G.A., Slith S.L., Zooplankton community pattern associated with a Calitornia Current cold filament, J. Geophys. Res. 96, C8, paper 14 (1991) 781-797.

[19] Razouls C., Kouwenberg, J.H.M., Spatial distribution and seasonal variation of mesozooplankton biomass in the Gulf of 1 ions (northwestern Mediterranean), Oceanol. Acta 16 (1993) 393-401.

[20] Razouls C.. Estimation de la Production secondaire (Copépodes pélagiques) dans une Province néritique méditerranéenne (Golfe du Lion), Univ. Paris-VI, Thèse Doct. (1972) 301 p.

[21] Seguin G., Dynamique des copépodes pélagiques en rade de Villefranche-sur-Mer à partir de prélèvements quotidiens (année 1972), Bilan quantitatif et écologique, Oceanol. Acta 4 (1981) 405-414.

[22] Smith S.L., Copepods in Fram strait in summer: Distribution, feeding and metabolisme, J. Mar. Res. 46 (1988) 145-181.

[23] Smith S.L., Jones B.H., Atkinson L.P. Brink K.H., Zooplank ton in the upwelling fronts off Pt. Conception, California, in: J.C.J. Nihoul (Ed.), Marine interfaces ecohydrodynamics, Elsevier Oceanogr. Ser. 42 (1986) 195-214.

[24] Thibault D., Gaudy R., Le Fèvre J., Zooplankton biomass, feeding and metabolism in a geostrophic frontal area (Almeria-Oran Front, western Mediterranean), Significance to pelagic food webs, J. Mar. Syst. 5 (1994), 297-311.

[25] UNESCO Zooplankton sampling, Monogr. Oceanogr. Methodol., 2, Paris, UNESCO press, 1968, 174 p.

[26] UNESCO Zooplankton fixation and preservation, Monogr. Oceanogr. Methodol., 4, Paris INESCO press, 1976, $350 \mathrm{p}$ 